\title{
Cyanobacterial Communities of Carbonate Sediments and Biomineralization in Peterhof Fountains' Water Supply System, Russia
}

\author{
Oksana A. Rodina ${ }^{1,2}, * \mathbb{E}$, Oleg S. Vereshchagin ${ }^{3} \mathbb{1}$, Dmitry Yu. Vlasov ${ }^{4}$, Marina S. Zelenskaya ${ }^{4}(\mathbb{D}$, \\ Dmitrii V. Pankin ${ }^{5}$, Nikita V. Mitrofanov ${ }^{1}$, Michael Yu. Nikitin ${ }^{6}$, Kseniia Yu. Vasileva ${ }^{7}$ \\ and Olga V. Frank-Kamenetskaya ${ }^{1}$ (D)
}

1 Department of Crystallography, Institute of Earth Sciences, Saint Petersburg State University, University Emb. 7/9, 199034 St. Petersburg, Russia; mitrofanow.nv@gmail.com (N.V.M.); ofrank-kam@mail.ru (O.V.F.-K.)

2 Laboratory of Flora and Plant Resources, Avrorina Polar-Alpine Botanical Institute of the Kola Scientific Center of the Russian Academy of Sciences, Md. Akademgorodok, 18A, 184209 Apatity, Russia

3 Department of Mineralogy, Institute of Earth Sciences, Saint Petersburg State University, University Emb. 7/9, 199034 St. Petersburg, Russia; o.vereshchagin@spbu.ru

4 Department of Botany, Saint Petersburg State University, University Emb. 7/9, 199034 St. Petersburg, Russia; dmitry.vlasov@mail.ru (D.Y.V.); marsz@yandex.ru (M.S.Z.)

5 Center for Optical and Laser Materials Research, Saint Petersburg State University, Ulyanovskaya St., 5a, 198504 St. Petersburg, Russia; dima-pankin@mail.ru

Citation: Rodina, O.A.; Vereshchagin, O.S.; Vlasov, D.Y; Zelenskaya, M.S.; Pankin, D.V.; Mitrofanov, N.V.; Nikitin, M.Y.; Vasileva, K.Y.; Frank-Kamenetskaya, O.V. Cyanobacterial Communities of Carbonate Sediments and Biomineralization in Peterhof Fountains' Water Supply System, Russia. Minerals 2021, 11, 1199 https://doi.org/10.3390/min 11111199

Academic Editors: Maxim Muravyov and Anna Panyushkina

Received: 14 October 2021

Accepted: 26 October 2021

Published: 28 October 2021

Publisher's Note: MDPI stays neutral with regard to jurisdictional claims in published maps and institutional affiliations.

6 Departmen of Historical and Dynamic Geology, Geological Survey Faculty, St. Petersburg Mining University, 21st Line, 2, 199106 St. Petersburg, Russia; boogiewoogieboy@mail.ru

7 Department of Sedimentary Geology, Institute of Earth Sciences, Saint Petersburg State University, University Emb. 7/9, 199034 St. Petersburg, Russia; k.vasilyeva@spbu.ru

* Correspondence: oksid93@bk.ru; Tel.: +7-999-209-02-89

\begin{abstract}
The role of cyanobacterial communities in the formation of carbonate sediments (ancient and modern) is not completely clear. We studied the cyanobacterial communities connected with carbonate sediments of the freshwater bodies feeding the historical Peterhof fountains (SaintPetersburg, Russia). Cyanobacterial communities were studied by metagenome analysis and optical microscopy. Carbonates associated with cyanobacterial communities (both in situ and in vitro) were studied by powder X-ray diffraction analysis, scanning electron microscopy, energy-dispersive X-ray spectroscopy, and Raman spectroscopy. The interconnection between the mineral composition of carbonate sediments and inhabiting microorganism species was established. The leading role of cyanobacteria in carbonate biomineralization in fresh water of Peterhof fountains water supply system was shown. Cyanobacteria of 24 genera were revealed in sediments composed of calcite and aragonite. The crystallization of carbonates on the surface of 13 species of cyanobacteria was found. Using model experiments, a significant contribution of cyanobacterial species of the Oscillatoriaceae family (Phormidium spp., Lyngbya sp., Oscillatoria formosa) to carbonate biomineralization is demonstrated.
\end{abstract}

Keywords: microbial community; cyanobacteria; biomineralization; freshwater carbonates

\section{Introduction}

Many studies have been focused on factors involving in the development of the sedimentary record of modern fluvial carbonate systems [1]. Tufa is a category of freshwater carbonate sediment that occurs at ambient temperature (cold water) at springs, waterfalls, and in fast-flowing streams [2,3]. Tufa precipitation concept evolved from pure abiotic control (i.e., precipitation of carbonates due to carbon dioxide outgassing [4]) via biotic control (i.e., biologically induced mineralization [2]) to a combination of both (abiotic/biotic) variants [5]. Recently, it was shown that that the presence of a microbial biofilm, in which cyanobacteria are often dominant, strongly influences the precipitation of carbonates in 
riverine freshwater settings [5-7]. These organisms are highly diverse and are widely found in terrestrial and aquatic ecosystems [8]. Cyanobacteria are Gram-negative bacteria [9], and in contrast to other prokaryotes (bacteria and archaea), they perform oxygenic photosynthesis and possess chlorophyll-a [10]. They play an important role in the formation of carbonates since the Archean [9]. Cyanobacteria are involved in the formation of calcite, aragonite, dypingite, hydromagnesite [9], and whewellite [11]. Despite significant research in this field, the relationship between cyanobacterial communities, environmental conditions, and deposited minerals is not fully understood to date.

Cyanobacteria from the genera Calotrix, Chamaesiphon, Gloeocapsa, Homoeothrix, Hydrococcus, Hydrocoleum, Geitleria, Phormidium, Rivularia, and Schizothrix can participate in biomineralization $[9,12,13]$ due to producing extracellular polymeric substances (EPSs), which play important roles in the deposition of carbonates. The EPS composition is species specific (depending on the set of genes) and also depends on environmental conditions and crystallization medium composition [14]. The aquatic environment dictates calcium concentration and dissolved inorganic carbon content, as well as $\mathrm{pH}$, and thus is essential for carbonate formation [15].

The water supply system of the fountains of Peterhof (historical museum reserve), Russia is a unique hydraulic system, consisting of 37 main water elements: 12 rivers and streams, 9 canals, 16 ponds [16,17]. The length of all watercourses is $56 \mathrm{~km}$. The largest watercourse in the system is the Shingarka River, which receives the spring flow of numerous streams. Carbonate sediments of the Fabrichnaya and Shingarka rivers are known since the 18th century, when the building's stone was mined in these places. The oldest deposits of carbonate tuffs in this region dated to the first half of the Holocene [18], and their formatting continues to this day, as evinced by the carbonate crusts on the sculptors of the Peterhof fountains [19]. Most carbonate sediments in this district have distinct biomorphic structures (Figure 1a,b), which suggests their biological origin [18]. However, no detailed analysis of biological communities and associated carbonate was carried out. Cyanobacteria form mucous matrices, which are habitats of other bacteria and form microenvironments that affect the processes of carbonate precipitation [14]. However, the question of whether certain types of cyanobacteria influence the processes of carbonate deposition remains open.

There are two approaches to better understanding microbial carbonate deposition. These are the study of natural samples of microbial communities and carbonate deposits and experimental laboratory modeling using pure cultures or microbial communities found in nature [20].

In this regard, the aims of this work were (1) to study mineral composition and species diversity of cyanobacteria of carbonate sediments in Peterhof fountains water supply system, (2) to reveal the interconnection between the mineral composition of carbonate sediments and inhabiting microorganisms species, and (3) to establish the contribution of cyanobacteria to carbonate formation in freshwater bodies using model experiments. 

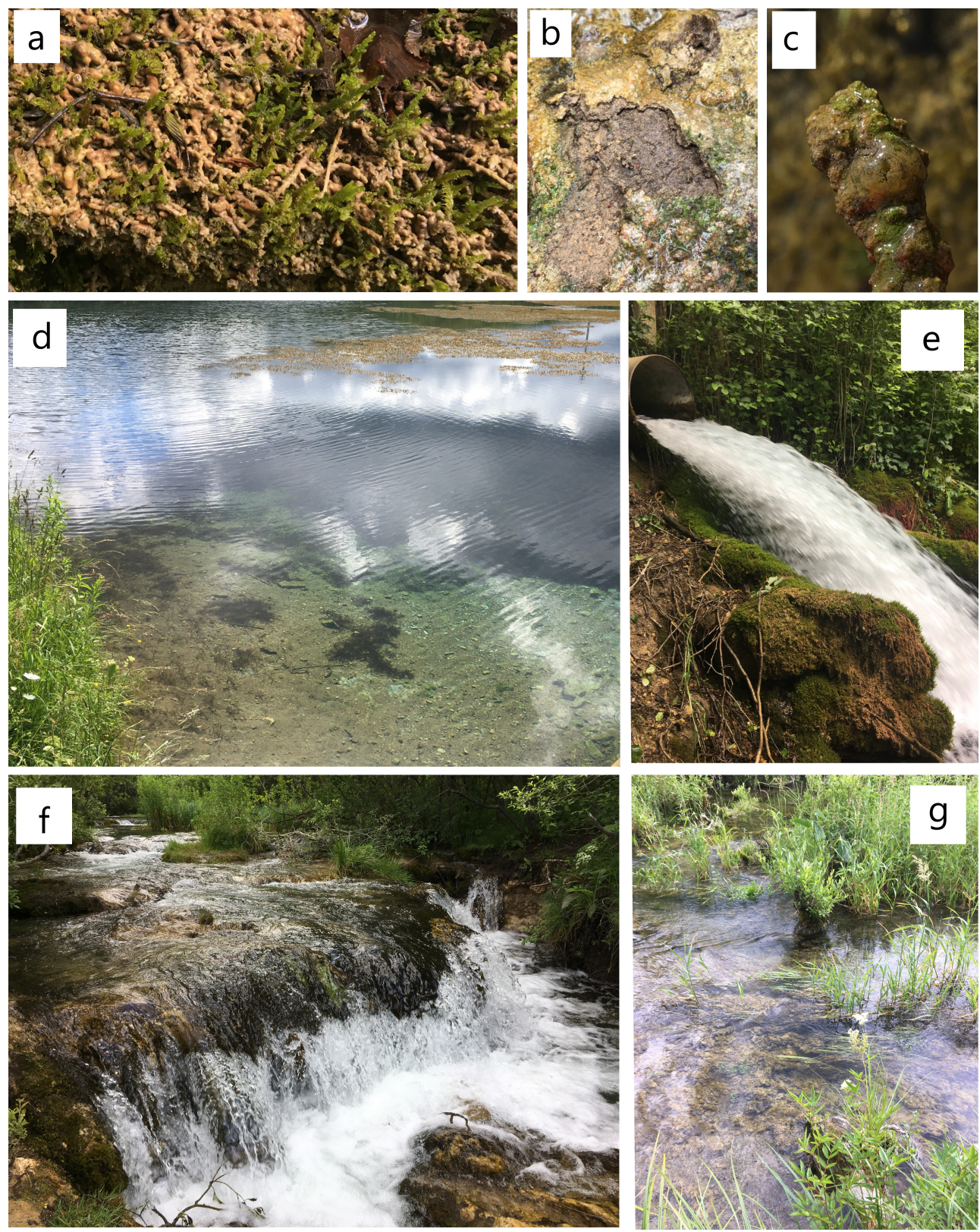

Figure 1. The sampling locations and natural carbonate sediments: (a) - mosses covered by carbonate sediments from the splash zone near the water discharge from the Glyadinskoe reservoir; (b) — carbonate sediment crust formed on a thin cyanobacterial mat; (c)_biofilm on carbonate sediment around the plant debris; (d)—Glyadinskoe reservoir; (e)—water discharge from the Glyadinskoe reservoir; (f) —waterfall on Simonovskiy stream; (g) -Fabrichnaya river.

\section{Materials and Methods}

\subsection{Study Area and Sample Collection}

Our study is based on materials collected from the southern vicinity of Saint Petersburg in the Lomonosov district near Orzhitsy village, Glyadino village, and the city of Peterhof (Figure 2a,b). The climate of the territory is temperate, with mild winters. The average air temperature is $8.6^{\circ} \mathrm{C}$, and the air humidity is $70 \%$. The main wind direction is south and southwest [21]. Neoproterozoic to Paleozoic sedimentary rocks are flat lying and overlap Archean to the Paleoproterozoic basement (granite and gneiss) with an angular unconformity [22]. Neoproterozoic conglomerate, gravel, sandstone, and clay (overall thickness is up to $300 \mathrm{~m}$ ) are succeeded by Cambrian deposits (thickness is up to $150 \mathrm{~m}$ ) 
composed of clay, siltstone, and sandstone; they are overlapped by the Lower Ordovician black shale and sandstone gradually replaced by limestone [23]. Middle-to-Upper Ordovician sediments are composed of limestones, partly dolomitized, and dolostones (the thickness of the Ordovician strata is up to $200 \mathrm{~m}$ ). Lower to Middle Ordovician clayey bioclastic limestones are exposed across the Shingarka River. Different stratigraphical levels of the Paleozoic rocks are overlaid by the Quarternary glacial, limnoglacial, or bog sediments, and the thickness of the Quarternary deposits do not exceed $20 \mathrm{~m}$ [24].
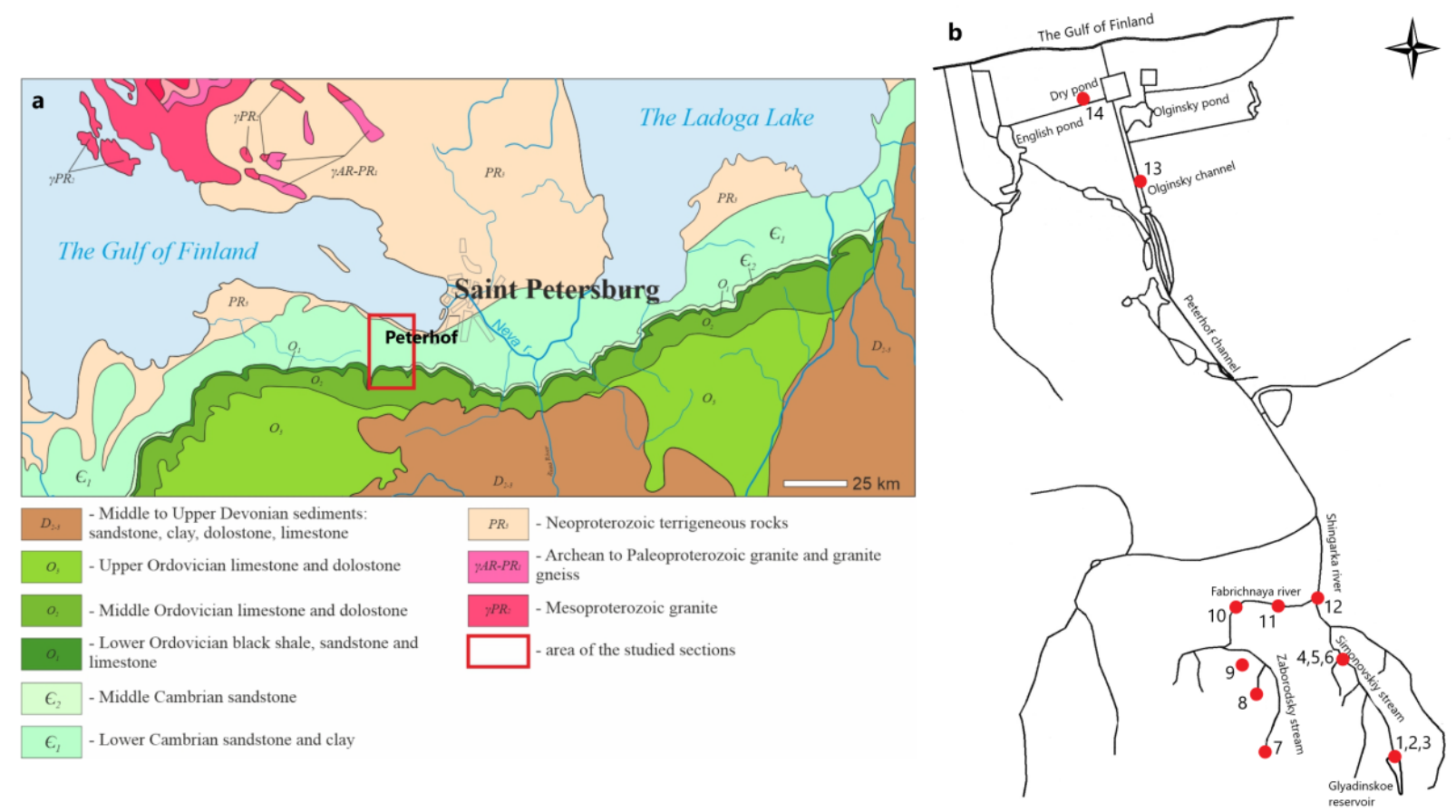

Figure 2. Characteristic of the studied area and sampling points: (a)—simplified geological map of the Leningrad region (following [24], with changes); (b)—schematic map of sampling points, numbers corresponding to Table 1.

Most of the freshwater carbonate sediments were formed in rivers and lakes, as well as near the places where groundwater emerged to the surface (Figure 2). Carbonate deposits are 1-3 m thick (rarely up to 7-8 $\mathrm{m}$ ) and are usually confined to slopes or relief depressions. The area of carbonate sediments depositions varies from hundreds of square meters to several square $\mathrm{km}$. Local foci of carbonate accumulation were found in the tributaries of the Shingarka River $[25,26]$. The largest deposits of calcareous tuffs in the area were developed until 1917 [18].

A total of 50 samples of carbonate sediments with biofilms were collected in 2018-2020 from water bodies of 6 different types (I-VI) connected with Peterhof fountains water supply systems: I—water reservoir (2 samples); II—river and streams (24 samples); IIIwaterfalls (8 samples); IV—splash zones (5 samples); V—springs (7 samples); VI—shallow artificial reservoirs (4 samples) (Table 1$)$. Samples were taken in sterile containers and craft envelopes, and water $\mathrm{pH}$ was measured at each sampling point using a portable $\mathrm{pH}$ meter. Samples with typical biofilms were selected for metagenomic study from nonanthropogenic habitats of the water bodies, which are feeding the Peterhof water supply system (Table 1). 
Table 1. Names and locations of samples, collected from Peterhof fountains water supply system.

\begin{tabular}{|c|c|c|c|c|c|}
\hline \multirow{2}{*}{$\begin{array}{l}\text { Sampling } \\
\text { Point }\end{array}$} & \multirow{2}{*}{ Water Bodies } & \multicolumn{2}{|c|}{ Coordinates } & \multirow{2}{*}{$\begin{array}{l}\text { Sample } \\
\text { Name }\end{array}$} & \multirow{2}{*}{$\begin{array}{c}\text { Habitat Types (Water } \\
\text { Flow) }\end{array}$} \\
\hline & & $\mathbf{N}$ & $\mathbf{E}$ & & \\
\hline 1 & Glyadinskoe reservoir & $59^{\circ} 42^{\prime} 52^{\prime \prime}$ & $29^{\circ} 46^{\prime} 31^{\prime \prime}$ & SB-1, SB-2 * & $\mathrm{I}(\mathrm{A})$ \\
\hline 2 & $\begin{array}{l}\text { Water discharge from the } \\
\text { reservoir }\end{array}$ & $59^{\circ} 42^{\prime} 52^{\prime \prime}$ & $29^{\circ} 46^{\prime} 31^{\prime \prime}$ & SB-3, BF /DCS-4 * & $\mathrm{III}(\mathrm{C})$ \\
\hline 3 & $\begin{array}{l}\text { Splash area near water } \\
\text { discharge }\end{array}$ & $59^{\circ} 42^{\prime} 52^{\prime \prime}$ & $29^{\circ} 46^{\prime} 31^{\prime \prime}$ & $\mathrm{BF} / \mathrm{DCS}-5 *$ & $\operatorname{IV}(\mathrm{E})$ \\
\hline 4 & Simonovskiy stream & $59^{\circ} 44^{\prime} 26^{\prime \prime}$ & $29^{\circ} 45^{\prime} 53^{\prime \prime}$ & $\begin{array}{c}\text { BF-6, BF-7, BF-8, } \\
\text { BF-9, BF-10, } \\
\text { DCS-11, DCS-12, } \\
\text { DCS-13, DCS-14, } \\
\text { LCS-15, DCS-16, } \\
\text { DCS-17, BF-18, } \\
\text { DCS-19 }\end{array}$ & $\mathrm{II}(\mathrm{B})$ \\
\hline 5 & $\begin{array}{l}\text { Waterfall on Simonovskiy } \\
\text { stream }\end{array}$ & $59^{\circ} 44^{\prime} 23^{\prime \prime}$ & $29^{\circ} 45^{\prime} 30^{\prime \prime}$ & $\begin{array}{c}\text { DCS-20, DCS-21, } \\
\text { DCS-22, DCS-23, } \\
\text { BF/DCS-24, } \\
\text { BF/DCS-25 * }\end{array}$ & $\operatorname{III}(\mathrm{C})$ \\
\hline 6 & Splash area near waterfall & $59^{\circ} 44^{\prime} 23^{\prime \prime}$ & $29^{\circ} 45^{\prime} 30^{\prime \prime}$ & $\begin{array}{c}\text { BF-26, SB/DCS-27, } \\
\text { BF/DCS-28, } \\
\text { BF/DCS-29* }\end{array}$ & $\mathrm{IV}(\mathrm{E})$ \\
\hline \multirow{3}{*}{7} & \multirow{3}{*}{$\begin{array}{l}\text { Bolshoye Zaborodie } \\
\text { village (spring, stream and } \\
\text { fire pond) }\end{array}$} & \multirow{3}{*}{$59^{\circ} 44^{\prime} 20^{\prime \prime}$} & \multirow{3}{*}{$29^{\circ} 45^{\prime} 6^{\prime \prime}$} & $\begin{array}{l}\text { SB-30, SB-31, SB-32, } \\
\text { BF-33 }\end{array}$ & $\mathrm{V}(\mathrm{A})$ \\
\hline & & & & $\begin{array}{c}\text { SB-34, DCS-35, } \\
\text { DCS-36, DCS-37 }\end{array}$ & $\mathrm{II}(\mathrm{B})$ \\
\hline & & & & LCS-38 & $\mathrm{VI}(\mathrm{D})$ \\
\hline 8 & $\begin{array}{l}\text { Spring } 1 \text { in the Maloye } \\
\text { Zaborodie village }\end{array}$ & $59^{\circ} 44^{\prime} 41^{\prime \prime}$ & $29^{\circ} 44^{\prime} 19^{\prime \prime}$ & BF-39, BF-40 & $\mathrm{V}(\mathrm{A})$ \\
\hline 9 & $\begin{array}{l}\text { Spring } 2 \text { in the Maloye } \\
\text { Zaborodie village }\end{array}$ & $59^{\circ} 45^{\prime} 11^{\prime \prime}$ & $29^{\circ} 44^{\prime} 44^{\prime \prime}$ & $\mathrm{BF} / \mathrm{DCS}-41$ & $\mathrm{~V}(\mathrm{~A})$ \\
\hline 10 & $\begin{array}{l}\text { Riverbed bend of the } \\
\text { Fabrichnaya river }\end{array}$ & $59^{\circ} 44^{\prime} 55^{\prime \prime}$ & $29^{\circ} 45^{\prime} 34^{\prime \prime}$ & $\mathrm{BF} / \mathrm{DCS}-42$ & $\mathrm{II}(\mathrm{B})$ \\
\hline 11 & Fabrichnaya river & $59^{\circ} 42^{\prime} 58^{\prime \prime}$ & $29^{\circ} 44^{\prime} 29^{\prime \prime}$ & $\begin{array}{l}\text { BF-43, BF- } 44 \\
\text { BF / DCS- } 45 \\
\text { BF/DCS- } 46^{*}\end{array}$ & $\mathrm{II}(\mathrm{B})$ \\
\hline 12 & $\begin{array}{c}\text { Confluence of } \\
\text { Fabrichnaya river and } \\
\text { Simonovskiy stream }\end{array}$ & $59^{\circ} 44^{\prime} 56^{\prime \prime}$ & $29^{\circ} 46^{\prime} 27^{\prime \prime}$ & BF/DCS-47 & $\mathrm{II}(\mathrm{B})$ \\
\hline 13 & Olginsky channel & $59^{\circ} 52^{\prime} 30^{\prime \prime}$ & $29^{\circ} 54^{\prime} 14^{\prime \prime}$ & LCS-48, LCS-48 & $\mathrm{VI}(\mathrm{D})$ \\
\hline 14 & Dry pond & $59^{\circ} 53^{\prime} 0^{\prime \prime}$ & $29^{\circ} 54^{\prime} 3^{\prime \prime}$ & LCS-50 & $\mathrm{VI}(\mathrm{D})$ \\
\hline
\end{tabular}

Note: sample names: BF—biofilms; DCS—dense carbonate sediment; SB—stones with green biofilm; LCS—loose carbonate sediment; habitats: I—water reservoir; II—river and streams; III—waterfalls; IV—splash zones; V—springs; VI—shallow artificial reservoirs; water flow: A—slow; B—moderate; C—fast; D—still water; E—variable; ${ }^{*}$-samples for metagenomic analyzes.

\subsection{Identification of Cyanobacteria}

Species identification of cyanobacteria was carried out using direct microscopy (Leica DM 1000 microscope) by morphological characteristics, using the identification guides [27-29]. Natural samples and accumulative pure cultures isolated in distilled water and in various nutrient media-namely, Gromov-6, Z8, and BG-11 [30-32], were used. Data on the geographical distribution of the species and their ecological characteristics were provided in accordance with the CRIS database [33,34] and by Davydov [35]. 
Metagenomic analysis of the prokaryotic community was carried out for some samples (Table 1) based on the nucleotide sequence of gene 16S rRNA. DNA was isolated according to the method described by Vladimirov [36]. Sample preparation of the libraries was carried out according to the recommendations described in the Metagenomic Library Prep Guide (Illumina) [37]. For the detection of cyanobacteria, primers were developed using a working solution containing a forward CYA359F and an equimolar mixture of two reversals 1:1 (CYA781Ra and CYA781Rb). For the second stage, the F + 2R equimolar mixture was used. The analysis was conducted by BioBeagle Co (St. Petersburg, Russia).

\subsection{Laboratory Experiments on Biomineral Precipitation}

Four precipitation experiments were conducted in natural water with the participation of cyanobacteria isolated from natural communities in studied habitats (DCS/BF-24, DCS/BF-41, DCS/BF-42, DCS/BF-45; Table 1). Samples of natural water (the initial pH of the medium was 8.7-8.9), together with the community of microorganisms, were placed in sterile containers with a volume of $120 \mathrm{~mL}$ and were exposed for 6 months at room temperature and natural light. The assessment of precipitated phases was carried out immediately after collection and after 6 months of exposure. Such environments are best suited for experiments with natural communities since they represent a complex microbiome, which contains microorganisms of different trophic levels. The use of natural water makes it possible to preserve the functioning of the natural community under suitable trophic conditions.

In order to clarify the role of different cyanobacterial species in carbonate sedimentation, carbonate precipitation experiments were also carried out with collection strains of cyanobacteria. Experiments were carried out in the mineral medium Gromov- 6 . The initial medium $\mathrm{pH}$ was 7. The use of the mineral medium (Gromov-6) was due to the fact that the strains of cyanobacteria used are kept in such medium in the Collection of Algae of Leningrad University (CALU). It also allowed the experiment to be conducted under controlled conditions. Experiments were provided in a liquid mineral medium in two variants: (1) Gromov-6 medium and (2) in Gromov-6 medium with a piece of marble as an additional source of calcium. The strains of cyanobacteria for this experiment were obtained from the international collection CALU, which is maintained at the Microorganisms Cultivation Resource Center at St. Petersburg State University (16 strains). The strains were selected in accordance with their collection site (water bodies of Peterhof, fouling of carbonate surfaces, mineralized environment): Synechococcus sp. (CALU 535), Pleurocapsa sp. (CALU 1126), Lyngbya aerugineocoerulca f. minor (CALU 557), Phormidium subfuscum (CALU 614), Phormidium favosum (CALU 623), Scytonema ocellatum (CALU 579), Calothrix sp. (CALU 794), Phormidium sp. (CALU 1072), Stigonema hormoides (CALU 1407), Gloetrichia echinulate (CALU 1819), Phormidium sp. (CALU 1550), Oscillatoria formosa (CALU 660), Leptolyngbya sp. (CALU 1171), Pseudanabaena sp. (CALU 1837), Nostoc sp. (CALU 1840), and Gloeocapsa sp. (CALU 1842). The experiment was carried out in Petri dishes for 9 months. As a control, a piece of marble was exposed in Gromov-6 medium without cyanobacteria.

\subsection{Mineral Identification}

Identification of biominerals, along with bedrock samples, was accomplished by powder X-ray diffraction (PXRD), scanning electron microscopy (SEM), energy-dispersive spectroscopy (EDS), and Raman spectroscopy. PXRD studies were carried out using a Miniflex II diffractometer (Rigaku, Japan), Cu ka radiation, 2-theta range 3-80, velocity of $2^{\circ} / \mathrm{min}$, and step size of $0.02^{\circ}$. The PDXL II software (version 2.8.4.0, Rigaku, Japan) was used to identify the mineral phases, accessing the International Centre for Diffraction Data (ICDD) database. SEM studies were carried out using a TM 3000 (Hitachi, Japan) electron microscope with an EDS (Oxford, Great Britain). Raman spectra were obtained on the Senterra spectrometer (Bruker, MA, USA) equipped with a $785 \mathrm{~nm}$ solid-state laser with $1 \mathrm{~mW}$ power under the sample. The spectra were recorded in the range from 80 to $3700 \mathrm{~cm}^{-1}$. The aperture was $25 \mu \mathrm{m} \times 1000 \mu \mathrm{m}$. The integration time was $100 \mathrm{~s}$ with 
6 repetitions. The device is equipped with an Olympus BX-51 microscope. The $100 \times$ objective with 0.9 numerical aperture was used for better spatial resolution. This made it possible to compare photographs obtained using an optical and electron microscope.

\section{Results and Discussion}

\subsection{Mineral Composition of Sediments in Peterhof Fountains' Water Supply System}

The following minerals were found in the samples from the Peterhof water supply system: calcite, aragonite, dolomite, quartz, feldspar (albite, microcline), and mica (Table 2). Silicates (quartz, feldspar, and mica) are parts of the underlying substrate material. Calcite and dolomite could be both parts of underlying bedrock (limestone/dolomite) and newly formed biominerals, whereas aragonite could be biomineral only, as no aragonite-bearing rocks are known in the studied region. Studied calcite contains a small admixture of magnesium (0.5-1.8 wt.\% MgO). According to the mineral composition the studied carbonate sediments can be divided into two groups: (1) microorganism related: aragonite \pm Mg-calcite (Figure 3a) and (2) abiogenic: dolomite \pm low-Mg calcite. Samples from model experiments were enriched in organic material with minor mineral components. Therefore, no reliable PXRD data were obtained, whereas Raman spectroscopy reveal the presence of calcite (based on lattice modes peaks at 155, 281 as soon as 710 and $1086 \mathrm{~cm}^{-1}$ originating from $\mathrm{v}_{4}$ (bending mode) and $\mathrm{v}_{1}$ (symmetric stretching mode) in carbonate ion typical for calcite [13] (Figure 3b).

Table 2. Mineral composition of water deposits and $\mathrm{pH}$ of water.

\begin{tabular}{|c|c|c|c|}
\hline Samples & Carbonates & Silicates & $\mathrm{pH}$ \\
\hline $\begin{array}{l}\text { BF-6, BF-7, BF-8, BF-9, BF-10, } \\
\text { BF/DCS-24, DCS-17, BF-18, }\end{array}$ & Calcite & Quartz & $8.0-8.86$ \\
\hline $\begin{array}{l}\text { DCS-11, DCS-13, } \\
\text { LCS-15 }\end{array}$ & Magnesian calcite & Quartz, feldspar & $8.0-8.5$ \\
\hline $\begin{array}{l}\text { DCS-12, DCS-14, } \\
\text { DCS-16 }\end{array}$ & Calcite & Quartz, feldspar & $8.0-8.5$ \\
\hline DCS-19 & Magnesian calcite & - & $8.0-8.5$ \\
\hline $\begin{array}{c}\text { BF-26, SB/DCS-27, BF/DCS-28, DCS-20, } \\
\text { DCS-22 }\end{array}$ & Calcite & Quartz & $8.0-8.5$ \\
\hline DCS-21, DCS-23 & Magnesian calcite & Quartz & $8.0-8.5$ \\
\hline SB-1 & Calcite, dolomite & Feldspar, mica, quartz & 8.0 \\
\hline SB-3 & Calcite & Quartz & 8.0 \\
\hline BF-43, BF-44, BF/DCS-45, BF/DCS-42 & Calcite & Quartz \pm mica & 8.92 \\
\hline DCS-41 & Calcite & - & 8.67 \\
\hline $\mathrm{BF} / \mathrm{DCS}-47$ & Calcite & - & 8.95 \\
\hline SB-30, SB-31, SB-32 & Calcite, dolomite & Quartz, feldspar, mica & 7.33 \\
\hline SB-34 & Calcite & - & 8.66 \\
\hline DCS-35, DCS-36 & Calcite & Quartz & $8.0-8.5$ \\
\hline DCS-37 & Magnesian calcite & Quartz & $8.0-8.5$ \\
\hline LCS-38 & Magnesian calcite, aragonite & Quartz & $8.0-8.5$ \\
\hline LCS-48 & Magnesian calcite, aragonite & Quartz & 8.0 \\
\hline LCS-49 & Magnesian calcite, aragonite & Quartz, feldspar & 9.0 \\
\hline LCS-50 & Magnesian calcite, aragonite & Quartz & 8.5 \\
\hline SB-2, BF/DCS-4, BF/DCS-5 & Calcite & Quartz, feldspar, mica & 8.0 \\
\hline
\end{tabular}


Table 2. Cont.

\begin{tabular}{cccc}
\hline Samples & Carbonates & Silicates & pH \\
\hline BF/DCS-25, & Calcite & Quartz, feldspar, mica & 8.1 \\
BF/DCS-29 & Calcite & Quartz, feldspar, mica & 8.2 \\
\hline BF/DCS-46 & Q & & \\
\hline
\end{tabular}

Note: $\mathrm{pH}$ was measured in the summer period.
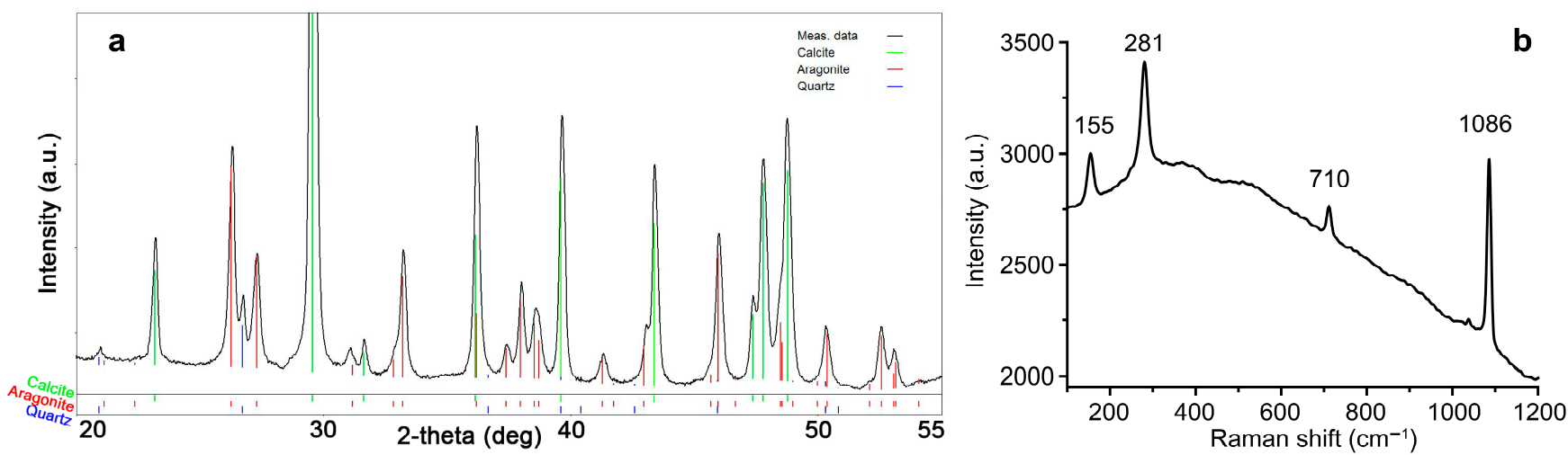

Figure 3. Examples of X-ray diffraction pattern (a) and Raman spectra (b) of carbonates: a-magnesium calcite and aragonite; (b)-calcite.

\subsection{Composition of Microbial Communities in Peterhof Fountains' Water Supply System}

The use of metagenomic analysis made it possible to identify cyanobacteria from 17 genera (Table 3). The most abundant (more than $15 \%$ share in the community) are Phormidium (47\%), Tychonema (27\%), Chamaesiphon (16\%), Leptolyngbya (15\%), Calothrix $(20 \%)$. In the splash zone, a community is represented by the genera Phormidium and Leptolyngbya. In riffle habitats Tychonema is dominant (22\% and $27 \%$ ). Additionally, a large share $(15 \%)$ is Leptolyngbya in the community with carbonate sediment located in the zone of water discharge from the reservoir.

Table 3. The list of cyanobacterial genera with participation in microbiome of studied habitats.

\begin{tabular}{|c|c|c|c|c|c|c|}
\hline \multirow{2}{*}{ Species } & \multicolumn{6}{|c|}{ Number of Sample, \% } \\
\hline & SB-2 & $\mathrm{BF} / \mathrm{T}-4$ & BF/T-25 & BF/T-46 & $\mathrm{BF} / \mathrm{T}-5$ & BF/T-29 \\
\hline Unclassified & 51.9 & 50.1 & 51.4 & 57.3 & 26.4 & 27.4 \\
\hline Phormidium_CYN64 & 3.7 & 1.3 & 3.1 & 8.4 & 47.6 & 44.9 \\
\hline Tychonema_CCAP_1459-11B & & 22.8 & 27.6 & 11.4 & & \\
\hline Chamaesiphon_PCC-7430 & 16.5 & 2.8 & 7.0 & 4.1 & 7.0 & 6.8 \\
\hline Leptolyngbya_ANT.L52.2 & & 15.3 & 0.3 & 0.4 & 11.0 & 12.4 \\
\hline Calothrix_KVSF5 & 20.5 & 5.7 & 3.2 & 6.2 & & \\
\hline Synechococcus_PCC-7502 & 3.4 & $\leq 0.01$ & 0.5 & 5.0 & 4.9 & 5.5 \\
\hline Leptolyngbya_FYG & $\leq 0.1$ & 1.3 & 4.8 & 3.7 & 0.5 & 0.6 \\
\hline Calothrix_PCC-6303 & & $\leq 0.1$ & 1.4 & 2.0 & 1.7 & 1.5 \\
\hline Pseudanabaena_PCC-7429 & 2.4 & $\leq 0.1$ & & 0.0 & & \\
\hline Phormidesmis_ANT.LACV5.1 & $\leq 0.01$ & 0.4 & & 1.3 & $\leq 0.1$ & 0.2 \\
\hline Leptolyngbya_ANT.L67.1 & & & & $\leq 0.1$ & 0.6 & 0.6 \\
\hline Geitlerinema_LD9 & $\leq 0.01$ & & 0.7 & $\leq 0.1$ & & \\
\hline
\end{tabular}


Table 3. Cont.

\begin{tabular}{|c|c|c|c|c|c|c|}
\hline \multirow{2}{*}{ Species } & \multicolumn{6}{|c|}{ Number of Sample, \% } \\
\hline & SB-2 & BF/T-4 & BF/T-25 & BF/T-46 & BF/T-5 & BF/T-29 \\
\hline Cyanobium_PCC-6307 & 0.6 & $\leq 0.1$ & & & & \\
\hline Pseudanabaena_PCC-6802 & 0.3 & & & & & $\leq 0.01$ \\
\hline Nodosilinea_PCC-7104 & & & & & & $\leq 0.1$ \\
\hline Oscillatoria_SAG_1459-8 & & & & & $\leq 0.1$ & \\
\hline Snowella_0TU37S04 & $\leq 0.01$ & & & & & \\
\hline
\end{tabular}

Note: samples designations correspond to Table 1.

The proportion of cyanobacteria in the microbiome ranges from $93 \%$ to $100 \%$ according to the results of metagenomic analysis (Figure 4). The share of Leptolyngbyaceae is higher in relation to other families in the Glyadinskoe reservoir (Figure 5). In places with a fast current (BF/DCS-4-water discharge, BF/DCS-25-waterfall), the proportion of Phormidiaceae is higher. Samples from the splash zones in Glyadino (BF/DCS-5) and at the waterfall (BF/DCS-29) are similar in the proportion of families in the microbiome. This is due to the fact that riffle habitats (fast water flow) and splash zones (variable humidity, temperature drops) are highly specific, and most often, such places are inhabited by species adapted to these habitat conditions [38,39]. A large amount of unclassified and unknown DNA is due to the fact that such communities remain poorly understood.

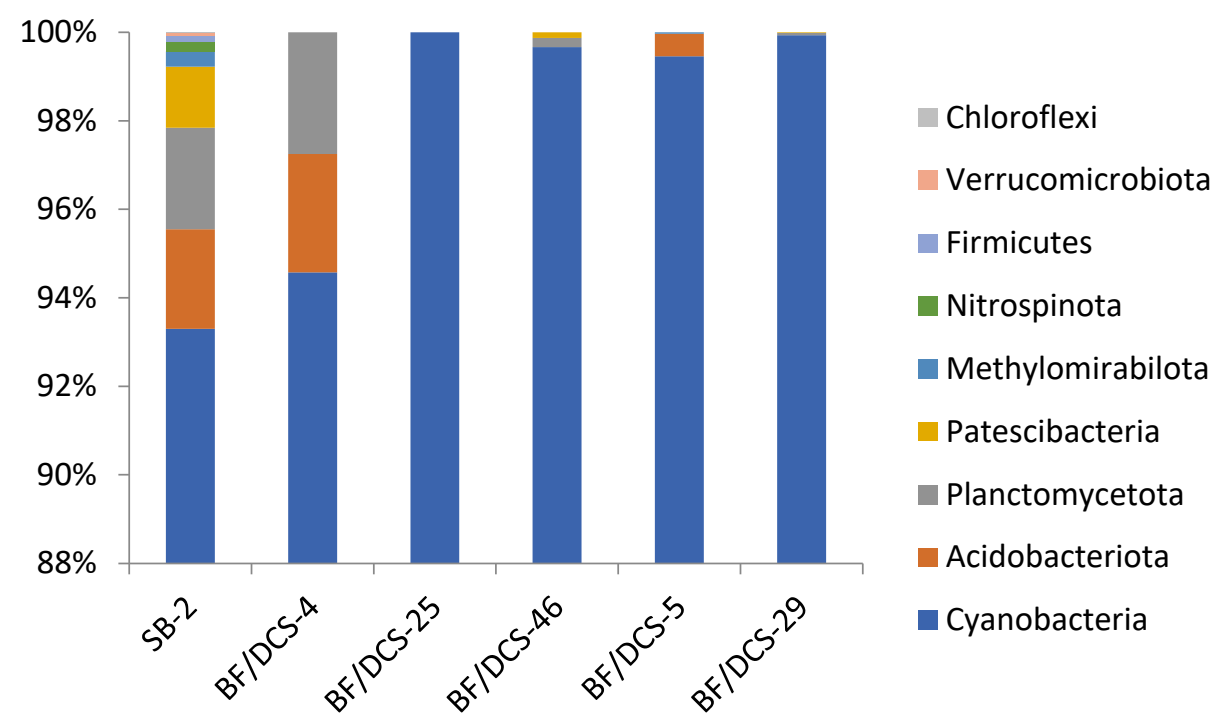

Figure 4. The proportion of cyanobacteria in the microbiome ranges (phyla level) of freshwater bodies feeding the historical fountains of Peterhof: SB-2-Glyadinskoe reservoir; BF/DCS-4-water discharge from the reservoir; BF/DCS-25—waterfall on Simonovskiy stream; BF/DCS-46-Fabrichnaya river; BF/DCS-5—splash area near water discharge; BF/DCS-29—splash area near waterfall; samples designations correspond to Table 1. 


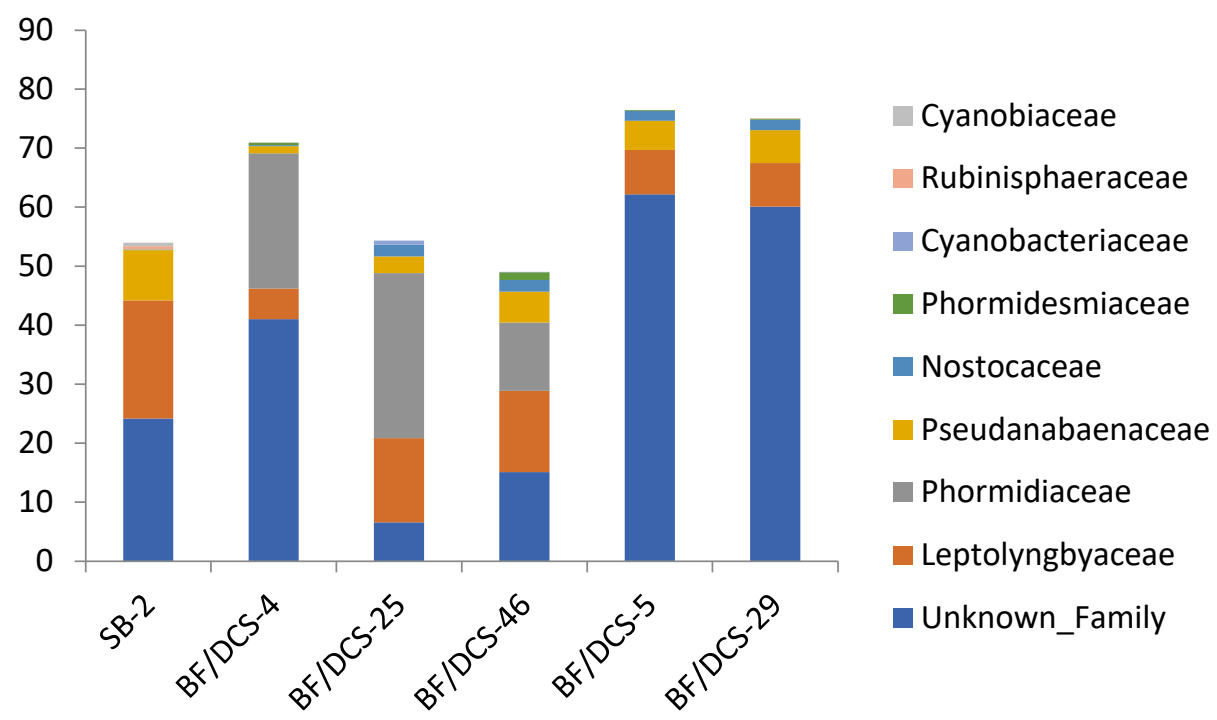

Figure 5. Representation of bacterial families (more than $1 \%$ in the microbiome) in the studied habitats $(\%$, samples designations correspond to Table 1$)$.

Unfortunately, it should be noted that the use of only metagenomic analysis may not reveal the full diversity of microorganisms in the study area. Several factors influence the DNA extraction processes (for example, the high amounts of EPS produced by Nostocales and Chroococcales [40] and a high concentration of $\mathrm{Mg}$ in nature samples [41,42]. A bias in relative abundances can be expected if only molecular methods are considered [43]. Therefore, it is necessary to use a set of methods to identify diversity.

In total, 25 species of cyanobacteria belonging to 16 genera, 11 families, and 4 orders were identified morphologically in the samples of carbonate sediments and biofilms (Table 4). The order Synechococcales is represented by the largest number of families (4). Filamentous forms of cyanobacteria are most widely represented in the order Oscillatoriales (10 species), while coccoid forms prevailed in the order Chroococcales (7 species). The genera Gloeocapsa and Phormidium turned out to be the richest in species diversity in comparison with other cyanobacteria. As a whole, 24 genera of cyanobacteria were identified as a result of morphological study and metagenomic analysis. The combination of the two approaches makes it possible to more fully assess the diversity of the studied microorganisms.

Table 4. Taxonomic list of identified cyanobacteria.

\begin{tabular}{|c|c|c|c|}
\hline Order & Families & Genus & Species \\
\hline \multirow{7}{*}{ Chroococcales } & \multirow{6}{*}{ Chroococcaceae } & Chroococcus & Chroococcus sp. \\
\hline & & Gloeocapsopsis & $\begin{array}{l}\text { Gloeocapsopsis crepidinum (Thuret) } \\
\text { Geitler ex Komárek }\end{array}$ \\
\hline & & \multirow{4}{*}{ Gloeocapsa } & Gloeocapsa calcarea Tilden \\
\hline & & & Gloeocapsa punctata Näg. ampl. Hollerb. \\
\hline & & & Gloeocapsa sp. \\
\hline & & & Gloeocapsa atrata Kützing, nom. illeg. \\
\hline & Microcystaceae & Microcystis & Microcystis pulverea (H.C.Wood) Forti \\
\hline \multirow{3}{*}{ Nostocales } & \multirow{2}{*}{ Nostocaceae } & \multirow{2}{*}{ Nostoc } & Nostoc punctiforme Hariot \\
\hline & & & Nostoc sp. \\
\hline & Microchaetaceae & Leptobasis & Leptobasis sp. \\
\hline
\end{tabular}


Table 4. Cont.

\begin{tabular}{|c|c|c|c|}
\hline Order & Families & Genus & Species \\
\hline \multirow{10}{*}{ Oscillatoriales } & \multirow[b]{2}{*}{ Coleofasciculaceae } & \multirow[b]{2}{*}{ Geitlerinema* } & Geitlerinema sp. \\
\hline & & & $\begin{array}{c}\text { Geitlerinema splendidum (Greville ex Gomont) } \\
\text { Anagnostidis }\end{array}$ \\
\hline & \multirow{3}{*}{ Microcoleaceae } & Kamptonema & $\begin{array}{c}\text { Kamptonema jasorvense (Vouk) Strunecký, } \\
\text { Komárek \& J.Smarda }\end{array}$ \\
\hline & & \multirow{2}{*}{ Microcoleus } & $\begin{array}{l}\text { Microcoleus autumnalis (Gomont) Strunecky, } \\
\text { Komárek \& J.R.Johansen }\end{array}$ \\
\hline & & & Microcoleus vaginatus Gomont ex Gomont \\
\hline & \multirow{5}{*}{ Oscillatoriaceae } & Oscillatoria * & Oscillatoria tenuis C.Agardh ex Gomont \\
\hline & & Lyngbya* & Lyngbya spp. \\
\hline & & \multirow{3}{*}{ Phormidium * } & $\begin{array}{l}\text { Phormidium animale (C.Agardh ex Gomont) } \\
\text { Anagnostidis \& Komárek }\end{array}$ \\
\hline & & & $\begin{array}{l}\text { Phormidium breve (Kützing ex Gomont) } \\
\text { Anagnostidis \& Komárek }\end{array}$ \\
\hline & & & Phormidium spp. \\
\hline \multirow{5}{*}{ Synechococcales } & Schizotrichaceae & Schizothrix & Schizothrix sp. \\
\hline & \multirow[t]{2}{*}{ Leptolyngbyaceae } & \multirow[t]{2}{*}{ Leptolyngbya* } & $\begin{array}{c}\text { Leptolyngbya laminosa (Gomont ex Gomont) } \\
\text { Anagnostidis \& Komárek }\end{array}$ \\
\hline & & & Leptolyngbya spp. \\
\hline & Merismopediaceae & Eucapsis & Eucapsis minor (Skuja) Elenkin \\
\hline & Pseudanabaenaceae & Pseudanabaena* & Pseudanabaena sp. \\
\hline
\end{tabular}

Note: ${ }^{*}$ —confirmed by metagenomic analysis.

Most diverse in taxa (15 taxa) was the sample of loose carbonate sediment from the Olginsky channel (Table 5). This is due to the fact that the Olginsky channel and Dry pond are subject to a greater anthropogenic load than other study sites. The presence of pipes that ensure the flow of water into the fountains of Peterhof adds microhabitats for the species. Cosmopolitan species of cyanobacteria, as well as species of stony substrates [44,45] (for example, Gloeocapsa atrata, Microcoleus autumnalis), have been noted. The appearance in the list of species characteristic of lithobiontic communities is most likely due to the fact that the coast of the Olginsky channel is fortified with stone slabs. A significant diversity of cyanobacteria was also noted in the Simonovskiy stream and Fabrichnaya river (10 species for each location). These sites are larger than springs and provide a variety of microhabitats for cyanobacteria. Species of the genera Leptolyngbya and Phormidium were most frequently found in the studied samples (Figure 6a,b). Phormidium was previously reported as the dominant periphyton species in the Leningrad Region rivers [46]. Species of the genus Lyngbya were found in splash zones and in large bodies of water, streams, and a river but not found in the reservoir and springs, and in Peterhof. Nostoc sp. (Figure 6c) and Pseudanabaena sp. (Figure 6d) are found in the Simonovskiy stream, Fabrichnaya river, and springs. In the sample form Dry pond, only one species was identified-Schizothrix sp. (Figure 6e), which was also recorded in the Olginsky channel.

Our study expands the list of cyanobacteria living in the carbonate sediments formation places in the Leningrad Region from 5 genera [13] to 24. Species of Oscillatoriales (Phormidium) and Synechococcales (Lepyolyngbya) predominate in such places. The data of metagenomic analysis are in significant agreement with the results of morphological identification and characterize the high diversity of cyanobacteria in the communities associated with the processes of carbonate sediment formation. The species composition changes depending on habitat conditions (reservoir, waterfall, stream, splash zone). Among the identified cyanobacteria, species confinement to certain habitats can be traced: for example, 
the predominance of species of the genus Tychonema is characteristic for riffle habitats. The genus Tychonema inhabits cold-water and slightly eutrophicated lakes [28]. For still water, an interesting picture is obtained. This type of water body is represented by the sample with the greatest diversity (15 species, LCS-48) and the sample with one species (Schizothrix sp., sample LCS-50). This fact testifies to the uneven distribution of cyanobacteria in such habitats that can also influence the formation of carbonate sediments.

Table 5. The occurrence of cyanobacterial species in sediments from the studied habitats and in carbonate sediments.

\begin{tabular}{|c|c|c|c|c|c|c|c|c|}
\hline \multirow{2}{*}{ Species } & \multicolumn{6}{|c|}{ Studied Habitats, Frequency } & \multicolumn{2}{|c|}{$\begin{array}{l}\text { Carbonate } \\
\text { Sediments }\end{array}$} \\
\hline & I & II & III & IV & $\mathbf{V}$ & VI & $\begin{array}{c}\text { Mg-Cc, } \\
\text { Ara }\end{array}$ & $\mathrm{Cc}$ \\
\hline Chroococcus sp. & & 1 & & & & & & + \\
\hline Eucapsis minor & & & & & & 1 & + & \\
\hline Geitlelinema sp. & & 2 & & & 1 & & & + \\
\hline $\begin{array}{l}\text { Geitlelinema } \\
\text { splendidum }\end{array}$ & & & 1 & & & & & + \\
\hline Gloeocapsa atrata & & & & & & 1 & + & \\
\hline Gloeocapsa calcarea & & & & & & 1 & + & \\
\hline Gloeocapsa punctata & & & & & & 1 & + & \\
\hline Gloeocapsa sp. & & 1 & 1 & & & & & + \\
\hline $\begin{array}{l}\text { Gloeocapsopsis } \\
\text { crepidinum }\end{array}$ & & & & & & 1 & + & \\
\hline $\begin{array}{c}\text { Kamptonema } \\
\text { jasorvense }\end{array}$ & & & & & & 1 & + & \\
\hline Leptobasis sp. & & & & & & 1 & + & \\
\hline $\begin{array}{c}\text { Leptolyngbya } \\
\text { laminosa }\end{array}$ & & & & & & 1 & + & \\
\hline Leptolyngbya spp. & 1 & 7 & 1 & 2 & 3 & 1 & + & + \\
\hline Lyngbya spp. & & 2 & & 1 & & & & + \\
\hline $\begin{array}{l}\text { Microcoleus } \\
\text { autumnalis }\end{array}$ & & 1 & & & & & & + \\
\hline $\begin{array}{c}\text { Microcoleus } \\
\text { vaginatus }\end{array}$ & & & & & & 1 & + & \\
\hline Microcystis pulverea & & & & & & 1 & + & \\
\hline Nostoc punctiforme & & & & & & 1 & + & \\
\hline Nostoc sp. & & 2 & & & 1 & & & + \\
\hline Oscillatoria tenuis & & & & & & 1 & + & \\
\hline Phormidium animale & & & 1 & & & & & + \\
\hline Phormidium breve & & 1 & & & & & & + \\
\hline Phormidium spp. & 1 & 1 & & & 3 & 1 & + & + \\
\hline Pseudanabaena sp. & & 1 & 1 & & 1 & & & + \\
\hline Schizothrix sp. & & & & & & 2 & + & \\
\hline Number of species & 2 & 10 & 5 & 2 & 5 & 15 & 15 & 12 \\
\hline
\end{tabular}

Notes: studied habitat designations (I, II, III, IV, VI) correspond with Table 1. 


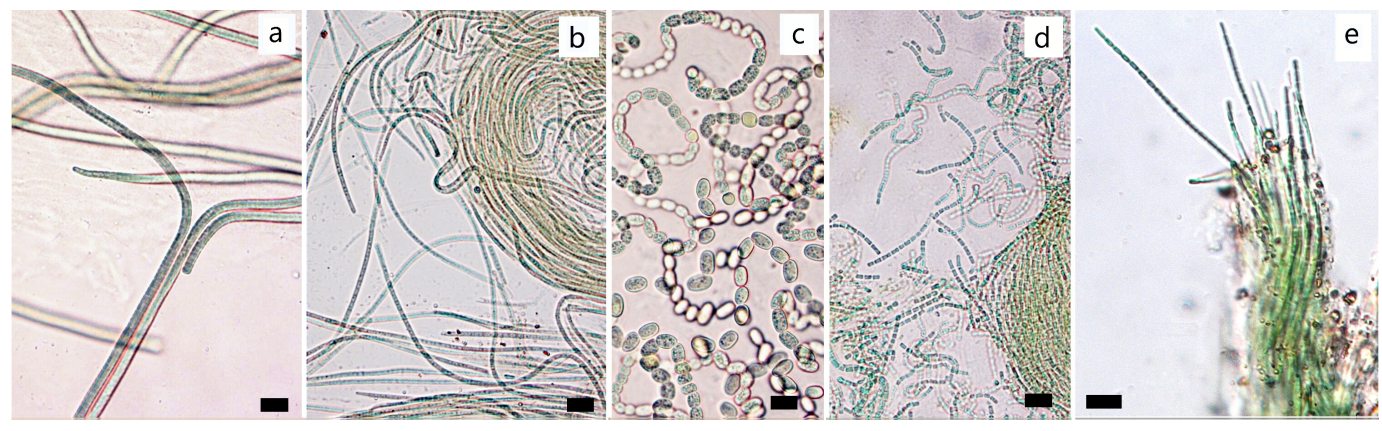

Figure 6. Some species of cyanobacteria identified in freshwater bodies: (a)_Phormidium sp.; (b)_Leptolyngbya sp.; (c)-Nostoc sp.; (d)—Pseudanabaena sp.; (e)—Schizothrix sp. Scale bar is $10 \mu \mathrm{m}$.

The studied community of microorganisms in freshwater bodies feeding the historical fountains of Peterhof is not only composed of prokaryotes. Eukaryotic algae make up a noticeable share of the autotrophic component. In all studied habitats, green algae Chlorophyta (coccoid and filamentous, for example, Cladophora sp., Klebsormidium sp.), as well as diatoms and Hydrurus sp. (Chrysophyta), were found.

3.3. Carbonate Precipitation in Fresh Water with the Participation of Cyanobacterial Species In Situ and In Vitro

It is possible to trace the connection of cyanobacteria with certain types of sediments using scanning electron microscopy. In carbonate sediments from the Dry pond (Table 1), cavities are clearly visible passing through the dense carbonate sediment area (Figure 7a), corresponding to trichomes of cyanobacteria (possibly Shizothrix). In the sediment from the waterfall of Simonovskiy stream, single trichomes of cyanobacteria surrounded by thick carbonate covers are clearly visible (Figure $7 \mathrm{~b}, \mathrm{c}$ ). Holes in the mass of sediments are also clearly visible, corresponding to cyanobacterial trichomes (Figure 7d).

In the 6 months course of the experiment on the precipitation of carbonates in laboratory conditions, the $\mathrm{pH}$ values of water decreased from 8.5-8.9 to 6.0, which could be connected with the binding of free $\mathrm{Ca}^{2+}$ ions to the biofilm EPS, the mass of which increases during the experiment and with the precipitation of calcium carbonate. In the biofilm with the domination of the cyanobacteria Phormidium spp., Geitlelinema sp., Pseudanabaena sp. grown in natural weakly alkaline water from the Symonovsky stream and Fabrichnay river, the formation of dumbbell-shaped crystals of calcium carbonates with $\mathrm{Mg} / \mathrm{Ca}$ ratio $\leq 0.008$ (Figure $8 \mathrm{a}$ ), and splices 30-45 $\mu \mathrm{m}$ long, $20 \mu \mathrm{m}$ wide (Figure 8b). For communities dominated by Lyngbya sp. the formation of intergrowths of acicular crystals characteristic of aragonite (the size of intergrowths $15-40 \mu \mathrm{m}$ ) was recorded (Figure 8c). In addition, thick carbonate covers $(\sim 15 \mu \mathrm{m})$ of complex composition $(\mathrm{Mg} / \mathrm{Ca}$ ratio $\leq 0.05)$ were observed around the Lyngbya trichomes (Figure 8d). Raman data showed the presence of calcite.

Calcite crystallization was also detected by Raman spectroscopy in experiments with monocultures of cyanobacteria. Calcite formation was obtained in experiments with 13 out of 16 strains (Synechococcus sp., Lyngbya aerugineocoerulca f. minor, Phormidium subfuscum, Phormidium favosum, Phormidium sp., Stigonema hormoides, Gloetrichia echinulate, Oscillatoria sp., Nostoc sp., Calothrix sp., Gloeocapsa sp.). Crystallization was not detected in the following cases:

- Cultures with Pleurocapsa sp., Scytonema ocellatum, Phormidium sp. (CALU 1550);

- In experiments without marble pieces with all cyanobacterial strains;

- In control (Gromov-6 medium with marble piece). 

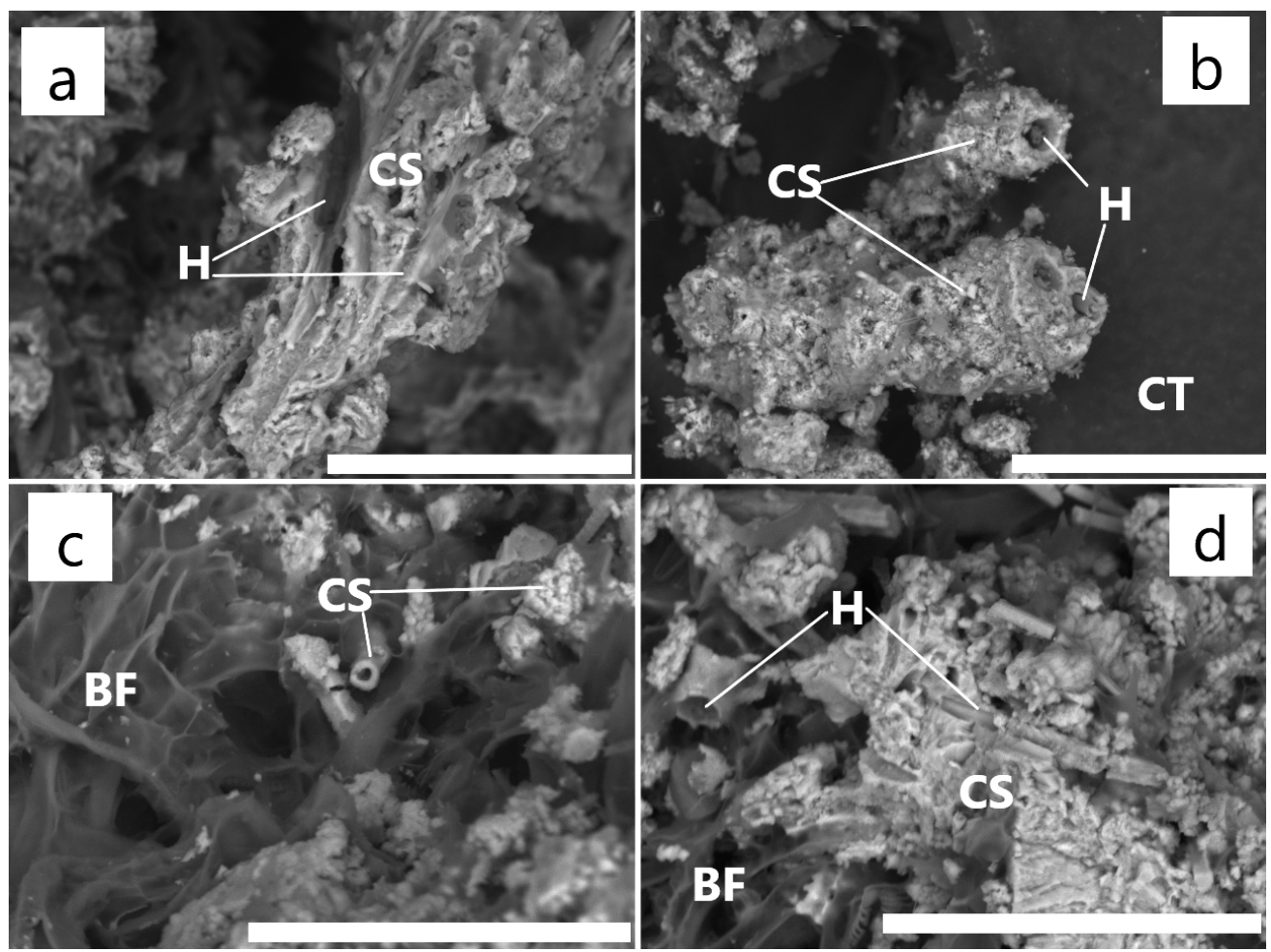

Figure 7. SEM images of carbonate sediments in the nature cyanobacterial biofilm: (a)—cavities in the mass of dense carbonate sediment (sample LCS-50); (b) - mineralized sheaths of filamentous cyanobacteria (BF/DCS-24); (c) - biofilm EPS with mineralized inclusions in the form of thin covers (sample BF/DCS-25); (d)—different diameter cavities in the mass of dense carbonate sediment (sample BF/DCS-25). Note: BF—biofilm, CS—carbonate sediments; CT—carbon tape; H-holes from the cyanobacterial trichomes. Scale bar $50 \mu \mathrm{m}$.

The newly formed calcite differs in morphology and chemical composition. In trichomes, Calothrix sp. single spherical globules (Figure $9 \mathrm{a})$ of low-Mg calcite $(<0.5 \mathrm{wt} . \%$ $\mathrm{MgO}$ ) were observed. Dumbbell-shaped (Figure $9 \mathrm{~b}$ ) intergrowths of needle high-Mg calcite crystals $(\mathrm{MgO}<3 \mathrm{wt} . \%)$ and spirally wrapped crystals (Figure 9c) up to $15 \mu \mathrm{m}$ in size were found in experiments with Synechococcus sp., Lyngbya aerugineocoerulca f. minor, Phormidium favosum, Phormidium sp., Pseudanabaena sp., Nostoc sp. The last one is similar to the morphology of carbonate sediments in natural community experiments with cyanobacterial species of the genera Phormidium and Pseudanabaena. Cover-shaped sediments (Figure 9d) were found in experiments with Phormidium subfuscum, Stigonema hormoides, Gloetrichia echinulate, Oscillatoria formosa, and Leptolyngbya sp.

Only two species of cyanobacteria-Phormidium sp. and Leptolyngbya sp.-were found in all types of sediments. Sediments with magnesian calcite and aragonite were recorded in the presence of the 15 species of 12 genera (Table 5). Metagenomic and morphological analysis data revealed 17 of 24 genera in sediments with calcite. Calcite and dolomite precipitation is in close association with EPS of coccoid organisms and cyanobacteria in springs [47]. In our studies, dolomite was found in sediment in the presence of Leptolyngbya sp., Phormidium sp., Geitlerinema sp. However, it was not observed in experiments on the carbonate sedimentation with these cyanobacterial species; this confirms that the dolomite is terrigenous. 

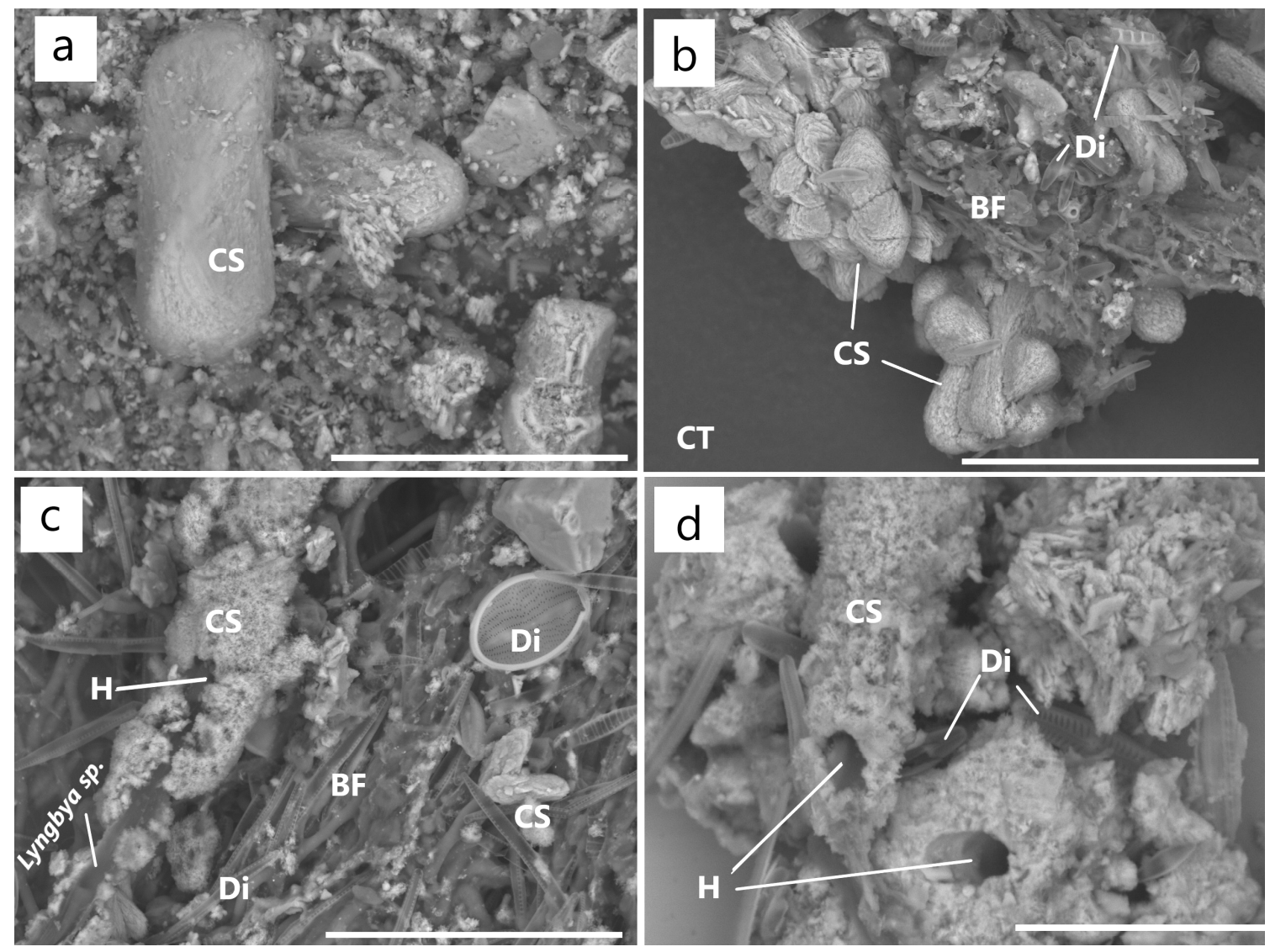

Figure 8. SEM images of calcite sediments formed in 6-month experiments: (a)—single calcite formation with spirally wrapped shape, scale bar $50 \mu \mathrm{m}$; (b) —splices 30-45 $\mu \mathrm{m}$ long of dumbbell-shaped crystals, scale bar $50 \mu \mathrm{m}$; (c) —calcite covers around the Lyngbya sp. (formation of intergrowths of acicular crystals) and dumbbell-shaped crystals, scale bar $50 \mu \mathrm{m}$; (d) - thick calcite covers $(\sim 15 \mu \mathrm{m})$ around the Lyngbya sp. similar to a natural sample (Figure $7 \mathrm{~b}$ ); scale bar $30 \mu \mathrm{m}$. Note: CS—calcite sediments; CT—carbon tape; BF—biofilm; Di-diatoms; H-holes from the cyanobacteria trichomes.

Lyngbya appears to be closely related to carbonate formation sites. Lyngbya species are characterized by the presence of a well-visible mucous cover, which is most likely associated with the processes of carbonate sedimentation. At the same time, aragonite was swollen in the Dry pond, which suggests that Schizothrix sp. affects the sedimentation of carbonates in the form of aragonite in the Dry pond and the Olginsky channel.

The genus Phormidium (in particular, Phormidium incrustatum) is the most frequently encountered and studied in carbonate sediments (Table 6) $[6,7,20,48]$. In our study, the species of the genus Phormidium are also among the frequently occurring species in biofilms associated with carbonate sediments in nature. Experiments in natural water and the Gromov-6 medium confirm the participation of Phormidium in calcite formation.

Obviously, the formation of carbonate sediments can be associated with differences in the cyanobacterial species but also with micro conditions that determine the development of cyanobacteria at a particular point. It was for still water that the formation of loose carbonate sediments was noted, in which the presence of aragonite was found. We also found that Schizothrix sp. is associated with the formation of aragonite in the studied water bodies. Earlier it was reported Schizothrix calcicola is involved in the deposition of carbonate sediments [49]. 

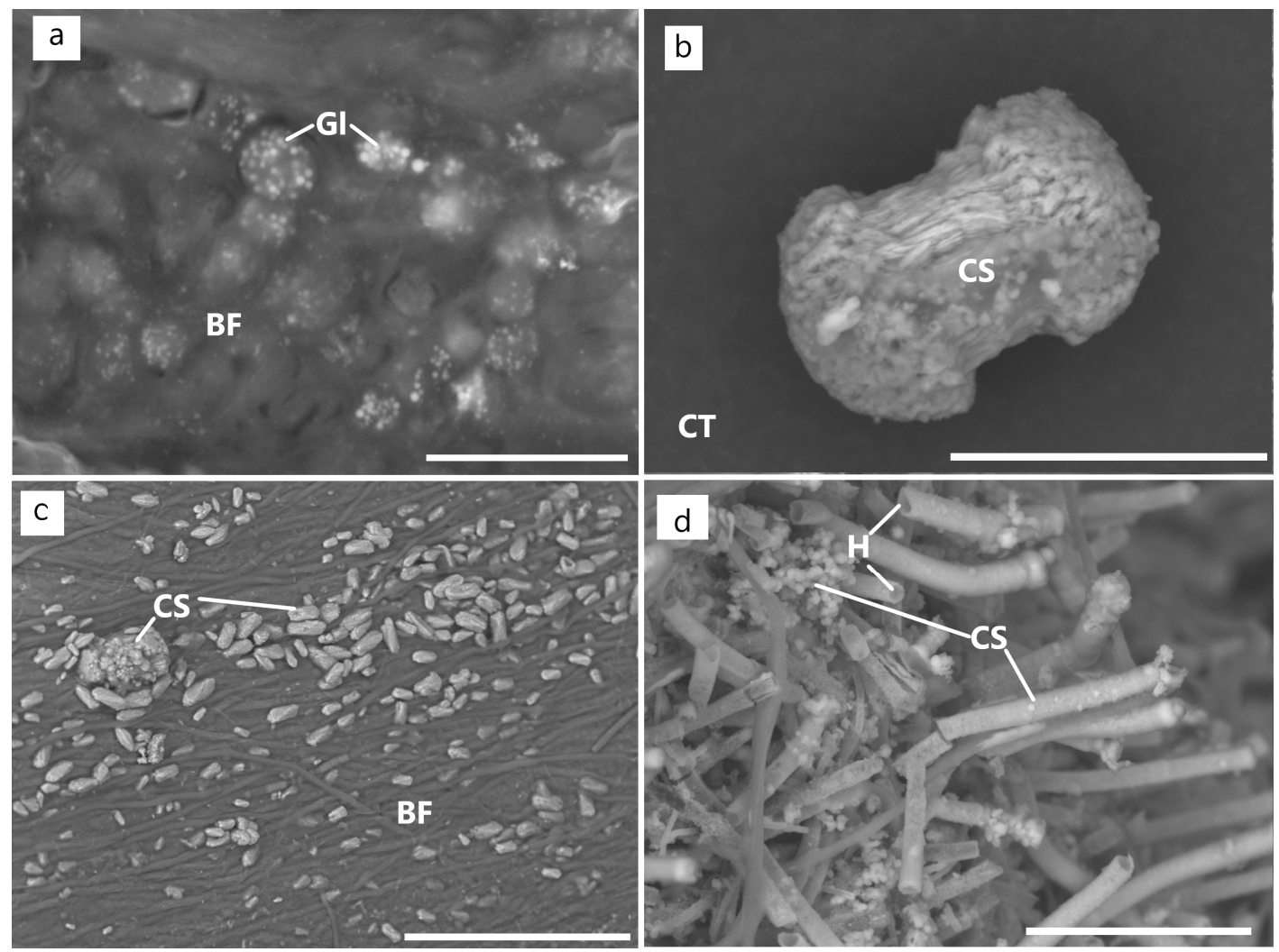

Figure 9. SEM images of carbonate sediments formed in 9-month experiments with cyanobacterial strains: (a)—single spherical globules in the Calothrix sp. trichomes, scale bar $30 \mu \mathrm{m}$; (b)_dumbbell-shaped calcite crystals from Pseudanabaena sp. culture, scale bar $30 \mu \mathrm{m}$; (c)—spirally wrapped calcite on the Lyngbya aerugineocoerulca f. minor trichomes, scale bar $100 \mu \mathrm{m} ;(\mathbf{d})$ - thick carbonate covers around the Oscillatoria formosa, scale bar $30 \mu \mathrm{m}$. Note: CS—calcite sediments; CT— carbon tape; BF—cyanobacterial biofilm; H—holes; cavities in sediments formed by cyanobacterial trichomes; Gl—globules.

Table 6. The participation of cyanobacteria in the carbonate sedimentation in fresh and mineralized water in nature and in experiments.

\begin{tabular}{|c|c|c|c|}
\hline Cyanobacteria & Environmental Conditions & Mineral & Ref. \\
\hline \multicolumn{4}{|c|}{ In vitro } \\
\hline $\begin{array}{c}\text { Anabaena, Calothrix, Phormidium, } \\
\text { Gloeocapsa }\end{array}$ & $\mathrm{Z} 8+\mathrm{MgSO} 4$ and $\mathrm{CaCl} 2$ & $\mathrm{Cc}$ & [50] \\
\hline Microcoleus chthonoplastes & $\begin{array}{c}\text { nutrient medium “S” + carbonate } \\
\text { sediment } 65 \% \mathrm{MgCO} 3+35 \% \mathrm{CaCO} 3 \\
\text { with monohydrocalcite }\end{array}$ & Ara, Mg-Cc, Dol, Dyp & [51] \\
\hline Scytonema julianum & $\begin{array}{c}\text { BG11+Agar+powedered calcium } \\
\text { carbonate }\end{array}$ & Cc, Acc & [52] \\
\hline $\begin{array}{l}\text { Biofilm with domination of the } \\
\text { cyanobacteria Phormidium spp., } \\
\text { Geitlelinema sp., Pseudanabaena sp. }\end{array}$ & Nature water in experiment & $\mathrm{Cc}$ & This study \\
\hline $\begin{array}{l}13 \text { strains of cyanobacteria from } \\
\text { CALU }\end{array}$ & $\begin{array}{l}\text { Gromov-6 mineral medium + piece of } \\
\text { marble (source of calcium ions) }\end{array}$ & $\mathrm{Cc}$ & This study \\
\hline $\begin{array}{l}\text { Biofilm with domination of the } \\
\text { cyanobacteria Lyngbya sp., } \\
\text { Phormidium sp., } \\
\text { Leptolyngbya sp. With diatoms }\end{array}$ & Nature water in experiment & Cc & This study \\
\hline
\end{tabular}


Table 6. Cont.

\begin{tabular}{cccc}
\hline Cyanobacteria & Environmental Conditions & Mineral & Ref. \\
\hline In situ & Soda lake & CC, Ara, Mg-Cc, Dol, & [53] \\
\hline Geitlerinema sp. and Nodosilinea sp. & Freshwater lakes & Wh, Cc & CC \\
\hline Gloeotrichia sp. & $\begin{array}{c}\text { A brackish technogenically altered } \\
\text { watercourse (Bogodelsky stream) }\end{array}$ & Cc & [11] \\
\hline $\begin{array}{c}\text { Preshwater rivers Hoyoux and } \\
\text { Triffoy, Belgium }\end{array}$ & Cc & [6] \\
\hline $\begin{array}{c}\text { Phormidiaceae and Oscillatoriaceae } \\
\text { filaments (inc. Tychonema) }\end{array}$ & $\begin{array}{c}\text { The stream (tributary of the Mérriver) } \\
\text { to the Southwest of Paris }\end{array}$ & Cc & [7,20] \\
\hline $\begin{array}{c}\text { Spirulina, Phormidium } \\
\text { Shizothrix sp. }\end{array}$ & $\begin{array}{c}\text { active hydrothermal systems (Central } \\
\text { Italy) }\end{array}$ & Mag-Cc, Ara & This study \\
\hline $\begin{array}{c}\text { Cyanobacteria community (inc. } \\
\text { Shizothrix sp.) with Phormidiaceae } \\
\text { domination }\end{array}$ & Freshwater pond (Dry pond) & Mag-Cc, Ara & This study
\end{tabular}

Community with Phormidium sp.,

Leptolyngbya sp., and other identified cyanobacteria

Freshwater springs

$\mathrm{Cc}$

This study

With diatoms and green algae

Note: Cc—calcite; Mag-Cc—magnesium calcite; Acc—amorphous calcium carbonate; Ara—aragonite; Dol—dolomite; Dyp—dypingite; Wh-whewellite.

Results of this work complement the information on the participation of different cyanobacteria in carbonate biomineralization. Based on the literature data and our research, the most promising in mineralization are filamentous nonheterocytic cyanobacteria from the families Phormidiaceae, Oscillatoriaceae, and Leptolyngbyacea. This has been noted both in nature and under experimental conditions. These organisms are capable of forming dense mats with high amounts of EPS. The presence of EPS controls the spatial distribution of carbonate crystals, being a low-energy substrate for crystal nucleation [54]. Additionally, organic compounds usually play a decisive role in carrying out precisely the initial stage of carbonate deposition into aqueous magnesium and aragonite carbonates [55].

Earlier, we carried out work on the determination of carbonate sediment in the fountains of Peterhof [19], the results of which revealed a greater variety of carbonates. At the same time, the diversity of cyanobacteria and other community members is higher in natural water bodies feeding the fountains. This is probably due to the anthropogenic load on the Peterhof fountains itself, reflected by the presence of heavy metals-related $(\mathrm{Pb}$, Sr) carbonates on fountains sculptures [19]. Conversely, previous studies of water from the Peterhof water supply system showed low content of heavy metals [56]. As a result, calcium (monohydrocalcite, aragonite), magnesium (dypingite, nesquehonite), lead, and strontium carbonates (strontianite-cerussite series) crystallize in the fountains [13].

Thus, it can be concluded that cyanobacteria in fresh water affect the precipitation of carbonate phases. Experiments with monocultures of cyanobacteria show different calcite morphologies and suggest that the morphology of carbonate sediments depends on the species composition of cyanobacteria. On the other hand, the differences in phase composition (i.e., mineral species) are influenced by abiotic factors. Additionally, diatoms are able to secrete an EPS such as cyanobacteria, forming colonies with a mucous matrix. These organisms could be important contributors to the mineralization process [20]. This process can also be due to the activity of bacteria symbionts of diatoms [57]. However, aerobic organisms are not the only organisms noted for the processes of carbonate sedimentation. Anaerobic photosynthetic bacteria are also able to reduce the concentration of $\mathrm{Ca}$ and form $\mathrm{CaCO}_{3}$ (mainly, calcite with some vaterite and monohydrocalcite) [49]. 
Despite the complexity of the microbial community at the sites of carbonate formation in fresh water, this study clearly showed that cyanobacteria play dominant roles in the biofilm community by forming their mucous matrix, thus affecting the carbonate sediment formation.

\section{Conclusions}

In the course of this work, carbonates sediments and cyanobacterial communities of the water supply system of Peterhof were studied. The interrelationships between the mineral composition of carbonate sediments and inhabiting microorganism species were established. It was shown that carbonate sediments are predominantly composed of calcite with a subordinate amount of aragonite and have a much lower mineral diversity in comparison with those studied by us earlier in the Peterhof fountains [19]. This fact can be associated with the following factors: (1) water circulation in closed systems of fountain bowls, which can locally lead to an increase in $\mathrm{pH}$ and magnesium concentration; (2) anthropogenic concentration of metals (e.g., $\mathrm{Pb}, \mathrm{Sr}$ ).

Despite the complexity of the microbial community at the sites of carbonate formation, the present study clearly showed that cyanobacteria play dominant roles in biomineralization in freshwater bodies. Using the results of model experiments and field observations, the crystallization of carbonates on the surface of 13 species of cyanobacteria was found. The significant contribution of cyanobacteria of the Oscillatoriaceae family (Phormidium spp., Lyngbya sp., Oscillatoria formosa) to carbonate crystallization was shown.

Author Contributions: Conceptualization, O.V.F.-K. and D.Y.V.; fieldwork, O.A.R., O.S.V., N.V.M., and M.Y.N.; PXRD studies, N.V.M. and O.S.V.; Raman studies, D.V.P.; laboratory experiments and cyanobacterial identification, O.A.R., M.S.Z., and D.Y.V.; writing-original draft preparation, O.A.R., O.S.V., D.Y.V., M.S.Z., D.V.P., N.V.M., M.Y.N., K.Y.V., and O.V.F.-K.; visualization, O.A.R., O.S.V., M.S.Z., and K.Y.V.; funding acquisition, O.V.F.-K. All authors have read and agreed to the published version of the manuscript.

Funding: This research was funded by the Russian Science Foundation, Grant Number 19-17-00141.

Acknowledgments: The laboratory studies were carried out in the Research Resource Centers of Saint Petersburg State University "Microscopy and microanalysis", "Nanotechnology", "Geomodel", "Center for optical and laser materials research", and "X-ray Diffraction Studies". The authors would like to thank Denis Aleksandrovich Davydov, senior researcher, Laboratory of Flora and Plant Resources, PABSI, for his help in identifying cyanobacterial species and Dina Danirovna Snarskaya, leading specialist of the Research Resource Center "Cultivation of Microorganisms" for preparing cultures of cyanobacteria for experiments.

Conflicts of Interest: The authors declare no conflict of interest.

\section{References}

1. Janssen, A.; Swennen, R.; Podoor, N.; Keppens, E. Biological and Diagenetic Influence in Recent and Fossil Tufa Deposits from Belgium. Sediment. Geol. 1999, 126, 75-95. [CrossRef]

2. Pedley, M. Freshwater (Phytoherm) Reefs: The Role of Biofilms and Their Bearing on Marine Reef Cementation. Sediment. Geol. 1992, 79, 255-274. [CrossRef]

3. Pentcost, A. Travertine; Springer: Berlin/Heidelberg, Germany, 2005; 445p, ISBN 978-1-4020-3523-4.

4. Irion, G.; Müller, G. Mineralogy, Petrology and Chemical Composition of Some Calcareous Tufa from the Schwäbische Alb, Germany. In Recent Developments in Carbonate Sedimentology in Central Europe; Müller, G., Friedman, G.M., Eds.; Springer: Berlin/Heidelberg, Germany, 1968; pp. 157-171. ISBN 978-3-642-88054-4.

5. Pedley, M.; Rogerson, M.; Middleton, R. Freshwater Calcite Precipitates from in Vitro Mesocosm Flume Experiments: A Case for Biomediation of Tufas. Sedimentology 2009, 56, 511-527. [CrossRef]

6. $\quad$ Kleinteich, J.; Golubic, S.; Pessi, I.S.; Velázquez, D.; Storme, J.-Y.; Darchambeau, F.; Borges, A.V.; Compère, P.; Radtke, G.; Lee, S.-J.; et al. Cyanobacterial Contribution to Travertine Deposition in the Hoyoux River System, Belgium. Microb. Ecol. 2017, $74,33-53$. [CrossRef]

7. Roche, A.; Vennin, E.; Bundeleva, I.; Bouton, A.; Payandi-Rolland, D.; Amiotte-Suchet, P.; Gaucher, E.C.; Courvoisier, H.; Visscher, P.T. The Role of the Substrate on the Mineralization Potential of Microbial Mats in A Modern Freshwater River (Paris Basin, France). Minerals 2019, 9, 359. [CrossRef] 
8. Dvořák, P.; Casamatta, D.A.; Hašler, P.; Jahodářová, E.; Norwich, A.R.; Poulíčková, A. Diversity of the Cyanobacteria. In Modern Topics in the Phototrophic Prokaryotes; Hallenbeck, P.C., Ed.; Springer International Publishing: Cham, Switzerland, 2017 ; pp. 3-46. ISBN 978-3-319-46259-2.

9. Kamennaya, N.; Ajo-Franklin, C.; Northen, T.; Jansson, C. Cyanobacteria as Biocatalysts for Carbonate Mineralization. Minerals 2012, 2, 338-364. [CrossRef]

10. Vidal, L.; Ballot, A.; Azevedo, S.M.F.O.; Padisák, J.; Welker, M. Introduction to cyanobacteria. In Toxic Cyanobacteria in Water, 2nd ed.; Chorus, I., Welker, M., Eds.; CRC Press: Boca Rataon, FL, USA, 2021; pp. 163-211. ISBN 978-1-00-308144-9.

11. Katkova, V.I.; Mityusheva, T.P.; Filippov, B.N.; Simakova, Y.S. Mineral inclusions in cyanobacretia from water objects of southern Komi Republic. Vestn. Kolskogo Nauchnogo Cent. RAN 2017, 9, 64-70. (In Russian)

12. Golubić, S.; Violante, C.; Plenković-Moraj, A.; Grgasović, T. Travertines and Calcareous Tufa Deposits: An Insight into Diagenesis. Geol. Croat. 2008, 61, 363-378. [CrossRef]

13. Kolokoltsev, V.G.; Nikitin, M.Y.; Kovalevskaya, E.O. Modern travertines in the St. Petersburg area. Priroda 2014, 7, 17-29. (In Russian)

14. Li, X.; Luo, K.; Ren, J.; Wang, X.; Mu, Q.; Fan, W. Characterisation of Extracellular Polymeric Substances from Different Cyanobacterial Species and Their Influence on Biocalcification Processes. Environ. Chem. 2017, 14, 254. [CrossRef]

15. Vereshchagin, O.S.; Frank-Kamenetskaya, O.V.; Kuz'mina, M.A.; Chernyshova, I.A.; Shilovskikh, V.V. Effect of Magnesium on Monohydrocalcite Formation and Unit-Cell Parameters. Am. Mineral. 2021, 106, 1294-1305. [CrossRef]

16. Ryabova, V.N.; Vasilieva, V.A. Vegetation restoration in recultivated ponds of the Lugovoy park (Petergof 's fountains water supply system). Biol. Commun. 2014, 4, 49-66. (In Russian)

17. Potravnov, A.L.; Khmelnik, T.Y. From the Kovashi River to the Samson Bowl: The History of the Water Supply System of the Peterhof Fountains; Avrora: St. Petersburg, Russia, 2019; ISBN 978-5-7300-0984-4. (In Russian)

18. Yu, N.M. Travertinogenesis of the Izhora Plateau in the Holocene: Dissertation of the Candidate of Geographical Sciences: 25.00.25/Nikitin Mikhail Yurievich; St. Petersburg State University: St. Petersburg, Russia, 2015; 197p. (In Russian)

19. Vereshchagin, O.S.; Frank-Kamenetskaya, O.V.; Shumilova, K.V.; Khadeeva, N.Y. Carbonate Sediments on Decorative Fountains in Peterhof, Russia. Environ. Earth Sci. 2018, 77, 56. [CrossRef]

20. Payandi-Rolland, D.; Roche, A.; Vennin, E.; Visscher, P.T.; Amiotte-Suchet, P.; Thomas, C.; Bundeleva, I.A. Carbonate Precipitation in Mixed Cyanobacterial Biofilms Forming Freshwater Microbial Tufa. Minerals 2019, 9, 409. [CrossRef]

21. Climate of Orzhitsy Village, Lomonosov District, Leningrad Region. Available online: https://goodmeteo.ru/pogoda-orzhitsylomonosovskiy-leningradskaya/god/ (accessed on 21 September 2021).

22. Popov, L.E.; Khazanovich, K.K.; Borovko, N.G.; Sergeeva, S.P.; Sobolevskaya, R.F. Reference Sections and Stratigraphy of the Cambro-Ordovician Phosphorite-Bearing Shell in the Northwest of the Russian Platform; Nauka: Leningrad, Russia, 1989; 222p, ISBN 978-5-02-024551-8. (In Russian)

23. Selivanova, A.V. Ordovician system. In Geology of the USSR. Vol. 1: Leningrad, Pskov and Novgorod Regions. Geological Description; Sidorenko, A.V., Ed.; Nedra: Moscow, Russia, 1971; pp. 127-173. (In Russian)

24. Verbitsky, V.R.; Verbitsky, I.V.; Vasilyeva, O.; Savanin, V.V. Hydr. State Geological Map of the Russian Federation; Scale 1:1,000,000 (Third Generation); Central European Series; Sheets O-35-Pskov, (N-35), O-36-St. Petersburg. Explanatory Letter; Cartographic Factory VSEGEI: St. Petersburg, Russia, 2012; 510p. (In Russian)

25. Kolokoltsev, V.G.; Auslender, V.G.; Kovalevskaya, E.O. The modern formation of calcareous tuffs in Leningrad region. Reg. Geol. Metallog. 2005, 23, 82-93. (In Russian)

26. Kolokoltsev, V.G.; Zhuravlev, A.V.; Kovalevskaya, E.O. Abiotic factors of modern fossilization of living plants in the vicinity of St. Petersburg. In Proceedings of the III International Symposium “Bioinert interactions: Life and Stone”, St. Petersburg, Russia, 26-29 June 2007; pp. 66-69. (In Russian).

27. Komárek, J.; Anagnostidis, K.; Komárek, J. Chroococcales; Cyanoprokaryota/Komárek, Jiř́i Unaltered Repr.; Spektrum Akademischer Verlag: Heidelberg, Germany, 2008; ISBN 978-3-8274-2111-1.

28. Komárek, J.; Anagnostidis, K.; Komárek, J. Oscillatoriales; Cyanoprokaryota/Komárek, Jiř́; Unaltered Repr.; 2. Print; Spektrum Akademischer Verlag: Heidelberg, Germany, 2008; ISBN 978-3-8274-1914-9.

29. Komárek, J.; Komárek, J. Heterocytous Genera; Cyanoprokaryota/Komárek, Jiř́i; Springer-Spektrum: Berlin/Heidelberg, Germany, 2013; ISBN 978-3-8274-0932-4.

30. Kotai, J. Instructions for Preparation of Modified Nutrient Solution Z8 for Algae. Nor. Inst. Water Res. 1972, 11, 5.

31. Rippka, R. Isolation and purification of cyanobacteria. In Methods in Enzymology; Elsevier: Amsterdam, The Netherlands, 1988; Volume 167, pp. 3-27. ISBN 978-0-12-182068-8.

32. Waterbury, J.B. The Cyanobacteria-Isolation, Purification and Identification. In The Prokaryotes; Dworkin, M., Falkow, S., Rosenberg, E., Schleifer, K.-H., Stackebrandt, E., Eds.; Springer: New York, NY, USA, 2006; pp. 1053-1073. ISBN 978-0-387-254944.

33. Melechin, A.; Davydov, D.; Shalygin, S.; Borovichev, E. Open information system on biodiversity cyanoprokaryotes and lichens CRIS (CRYPTOGAMIC RUSSIAN INFORMATION SYSTEM). Bull. Mosc. Soc. Nat. Biol. Ser. 2013, 118, 51-56. (In Russian)

34. Melekhin, A.V.; Davydov, D.A.; Borovichev, E.A.; Shalygin, S.S.; Konstantinova, N.A. CRIS—Service for Input, Storage and Analysis of the Biodiversity Data of the Cryptogams. Folia Cryptogam. Est. 2019, 56, 99-108. [CrossRef] 
35. Davydov, D. Peculiarity (property) geographical distribution and analysis Cyanoprokaryota (Cyanobacteria) by the example of biota Murmansk region. Bull. Mosc. Soc. Nat. Biol. Otd. Biol. 2010, 115, 43-54. (In Russian)

36. Vladimirov, I.A.; Matveeva, T.V.; Lutova, L.A. Real-Time PCR to Study the Spread of Agrobacteria; Galanika: St. Petersburg, Russia, 2014; p. 67. ISBN 978-5-906555-86-1. (In Russian)

37. 16S Metagenomic Sequencing Library Preparation. Available online: https://www.illumina.com/content/dam/illuminasupport/documents/documentation/chemistry_documentation/16s/16s-metagenomic-library-prep-guide-15044223-b.pdf (accessed on 11 August 2021).

38. Blum, J.L. The Ecology of River Algae. Bot. Rev. 1956, 22, 291-341. [CrossRef]

39. Fritsch, F.E. The encrusting algal communities of certain fast-flowing streams1. New Phytol. 1929, 28, 165-196. [CrossRef]

40. Wu, J.; Xi, C. Evaluation of Different Methods for Extracting Extracellular DNA from the Biofilm Matrix. Appl. Environ. Microbiol. 2009, 75, 5390-5395. [CrossRef] [PubMed]

41. Wade, B.D.; Garcia-Pichel, F. Evaluation of DNA Extraction Methods for Molecular Analyses of Microbial Communities in Modern Calcareous Microbialites. Geomicrobiol. J. 2003, 20, 549-561. [CrossRef]

42. Gómez-Acata, E.S.; Centeno, C.M.; Falcón, L.I. Methods for Extracting 'omes from Microbialites. J. Microbiol. Methods 2019, 160, 1-10. [CrossRef]

43. Águila, B.; Alcántara-Hernández, R.J.; Montejano, G.; López-Martínez, R.; Falcón, L.I.; Becerra-Absalón, I. Cyanobacteria in Microbialites of Alchichica Crater Lake: A Polyphasic Characterization. Eur. J. Phycol. 2021, 1-16. [CrossRef]

44. Davydov, D.A.; Patova, E. The Diversity of Cyanoprokaryota from Freshwater and Terrestrial Habitats in the Eurasian Arctic and Subarctic. In Proceedings of the 20th IAC Cyanophyte/Cyanobacteria Research Symposium 2016 Ordinal: 20th Affiliation, Innsburck, Austria, 28 August-2 September 2016. [CrossRef]

45. Uher, B. Cyanophytes/Cyanobacteria in the Gorges of the National Park Slovak Paradise. Master's Thesis, Comenius University, Bratislava, Slovakia, 2001. [CrossRef]

46. Stanislavskaja, E.V.; Gorchenko, A.S. Variety of periphyton algae in tributaries of Lake Ladoga. Nov. Sist. Nizshih Rastenij 2005, 39, 89-108. (In Russian)

47. García-Del-Cura, M.Á.; Sanz-Montero, M.E.; De-los-Ríos, M.A.; Ascaso, C. Microbial Dolomite in Fresh Water Carbonate Deposits. Sedimentology 2014, 61, 41-55. [CrossRef]

48. Pentecost, A. Taxonomic Identity, Ecology and Distribution of the Calcite-Depositing Cyanobacterium Phormidium Incrustatum (Oscillatoriaceae). Cryptogam. Algol. 2003, 24, 307-321.

49. Sharp, J.H. Blue-green algae and carbonates Schizithrix calcicola and algal stromatolites from Bermuda1: Schizithrix calcicola and algal stromatolites. Limnol. Oceanogr. 1969, 14, 568-578. [CrossRef]

50. Ivanova, Z.D.; Tsyrenova, D.D.; Barkhutova, D.D. Role of cyanobacteria in mineral formation in the hot source Alla (Buryatia). Bull. Buryat State Univ. Biol. Geogr. 2018, 88, 34-41. (In Russian) [CrossRef]

51. Zaitseva, L.V.; Orleanskii, V.K.; Alekseev, A.O.; Ushatinskaya, G.T.; Gerasimenko, L.M. Transformation of Carbonate Minerals in a Cyano-Bacterial Mat in the Course of Laboratory Modeling. Microbiology 2007, 76, 342-356. [CrossRef]

52. Ariño, X.; Hernandez-Marine, M.; Saiz-Jimenez, C. Colonization of Roman Tombs by Calcifying Cyanobacteria. Phycologia 1997, 36, 366-373. [CrossRef]

53. Samylina, O.S.; Zaitseva, L.V.; Sinetova, M.A. Participation of the algo-bacterial community in the formation of modern stromatolites in the Petukhovskoe soda lake (Altai Territory). Paleont. J. 2016, 2016, 92-101. (In Russian) [CrossRef]

54. Della Porta, G.; Hoppert, M.; Hallmann, C.; Schneider, D.; Reitner, J. The Influence of Microbial Mats on Travertine Precipitation in Active Hydrothermal Systems (Central Italy). Depositional Rec. 2021, dep2.147. [CrossRef]

55. De Boever, E.; Brasier, A.T.; Foubert, A.; Kele, S. What Do We Really Know about Early Diagenesis of Non-Marine Carbonates? Sediment. Geol. 2017, 361, 25-51. [CrossRef]

56. Cleaning the Olginsky Canal of the Water Supply System of the Fountains of Peterhof in Order to Preserve the Cultural Heritage Site; Technical Report on the Results of Environmental Engineering Surveys for the Preparation of Project Documentation; IEI: St. Petersburg, Russia, 2016; Volume 1.4, pp. 307-316, Unpublished Work. (In Russian)

57. Gomez, F.J.; Mlewski, C.; Boidi, F.J.; Farías, M.E.; Gérard, E. Calcium Carbonate Precipitation in Diatom-Rich Microbial Mats: The Laguna Negra Hypersaline Lake, Catamarca, Argentina. J. Sediment. Res. 2018, 88, 727-742. [CrossRef] 